\title{
DEVELOPMENTS IN INTELLECTUAL PROPERTY LAW: OCTOBER 1, 2014 - SEPTEMBER 30, 2015
}

\author{
Trevor CARTER ${ }^{*}$ \\ TRENTON MORTON ${ }^{* *}$ \\ REID DODGE ${ }^{* * *}$
}

This Article addresses recent developments in intellectual property law. In particular, this Article provides an overview and discussion of nine pivotal intellectual property law cases decided or argued between October 1, 2014 and September 30, 2015. Eight cases address issues of patent law and one case addresses trademark law. The cases are:

- Teva Pharmaceuticals USA, Inc. v. Sandoz, Inc. ${ }^{1}$

- In re Cuozzo Speed Technologies, LLC ${ }^{2}$

- Williamson v. Citrix Online, $L L C^{3}$

- Kimble v. Marvel Entertainment, $L L C^{4}$

- Commonwealth Scientific \& Industrial Research Organisation v. Cisco Systems, Inc. ${ }^{5}$

- Halo Electronics, Inc. v. Pulse Electronics, Inc. ${ }^{6}$ and Stryker Corp. v. Zimmer, Inc. ${ }^{7}$

- Apple, Inc. v. Samsung Electronics Co. ${ }^{8}$

- Hana Financial, Inc. v. Hana Bank

I. Claim Construction: Teva Pharmaceuticals USA, InC. V. Sandoz, InC.

The Supreme Court issued its decision in Teva Pharmaceuticals USA, Inc. v. Sandoz, Inc. on January 20, 2015. ${ }^{10}$ The issue before the Court was whether the Federal Circuit should apply a de novo or clear error standard when evaluating findings of fact made by a district court in the process of construing patent claims during claim construction. ${ }^{11}$ The majority held that when reviewing a district court's resolution of subsidiary factual issues decided during claim construction,

* Trevor Carter is a partner with the law firm Faegre Baker Daniels LLP in Indianapolis, Indiana.

** Trenton Morton is an associate in Faegre Baker Daniels's Indianapolis, Indiana office.

*** Reid Dodge is an associate in Faegre Baker Daniels's Indianapolis, Indiana office.

1. 135 S. Ct. 831 (2015).

2. 793 F.3d 1268 (Fed. Cir. 2015), cert. granted, 136 S. Ct. 890 (2016).

3. 792 F.3d 1339 (Fed. Cir. 2015) (en banc).

4. 135 S. Ct. 2401 (2015).

5. 809 F.3d 1295 (Fed. Cir. 2015).

6. 769 F.3d 1371 (Fed. Cir. 2014), petition for reh'g en banc denied, 780 F.3d 1357 (Fed. Cir. 2015), cert. denied, 136 S. Ct. 236 (2015).

7. 782 F.3d 649 (Fed. Cir. 2014), cert. granted in part, 136 S. Ct. 356 (2015).

8. 786 F.3d 983 (Fed. Cir. 2015), cert. granted in part, 136 S. Ct. 1453 (2016).

9. 135 S. Ct. 907 (2015).

10. 135 S. Ct. 831 (2015).

11. Id. at 835 .

http://dx.doi.org/10.18060/4806.01128 
the Federal Circuit must apply a clear error standard. ${ }^{12}$ Justice Thomas authored a dissenting opinion that Justice Alito joined. ${ }^{13}$

\section{A. The Majority Opinion}

In the majority opinion, authored by Justice Breyer, the Supreme Court held the proper standard of review for factual findings made by a district court during the process of construing patent claims is clear error, not de novo. ${ }^{14}$

The dispute between Teva and Sandoz centered on the meaning of the words "molecular weight" appearing in a patent claim. ${ }^{15}$ Teva owned the relevant patent, which covered a method of manufacturing the drug Copaxone, used to treat multiple sclerosis. ${ }^{16}$ Teva sued Sandoz for infringing the patent by manufacturing a generic version of the drug. ${ }^{17}$ The active ingredient in Copaxone, "copolymer1 ," is comprised of molecules with varying sizes. ${ }^{18}$ The relevant claim includes a limitation "molecular weight of 5 to 9 kilodaltons." 19

Sandoz argued the "molecular weight" limitation did not satisfy the definiteness requirement set out in 35 U.S.C. $\S 112 \uparrow 2 .{ }^{20}$ The district court, after evaluating evidence from expert witnesses, concluded the term was sufficiently definite because a person of skill in the art would understand that the term should be evaluated using the first of three different calculation methods that were known in the field and that Sandoz argued caused the term to be indefinite. ${ }^{21}$

On appeal, the Federal Circuit disagreed with the district court and found the term "molecular weight" indefinite. ${ }^{22}$ In doing so, the Federal Circuit reviewed all aspects of the district court's claim construction under a de novo standard, including findings of subsidiary fact. ${ }^{23}$ Teva filed a petition for certiorari to the Supreme Court, arguing the Federal Circuit applied the wrong standard when evaluating the district court's subsidiary findings of fact. ${ }^{24}$

The opinion of the Court began with a discussion of Federal Rule of Civil Procedure ("FRCP") 52(a)(6), which states that a court of appeals "must not . . . set aside" a district court's "[f]indings of fact" unless they are "clearly erroneous." 25 The Court explained that "[i]n our view, this rule and the standard

12. $I d$

13. Id. at 844 .

14. Id. at 835 .

15. Id.

16. $I d$.

17. Id.

18. Id.

19. Id.

20. Id. at 835-36.

21. Id. at 836 .

22. $I d$.

23. $I d$.

24. Id.

25. Id. 
it sets forth must apply when a court of appeals reviews a district court's resolution of subsidiary factual matters made in the course of its construction of a patent claim." ${ }^{.26}$ According to the Court, the rule "does not make exceptions or purport to exclude certain categories of factual findings from the obligation of a court of appeals to accept a district court's findings unless clearly erroneous."27

Nor did the Court's decision in Markman v. Westview Instruments, Inc., ${ }^{28}$ create any such exception. ${ }^{29}$ The Court stated that its decision in Markman (i.e., that claim construction is an issue of law) did not create an exception under which factual findings underlying a claim construction ruling should be exempt from the clear error review standard set out in FRCP 52 (a).$^{30}$ The Court also cited practical considerations favoring the clear error standard-given the technical nature of patent law,

[a] district court judge who has presided over, and listened to, the entirety of a proceeding has a comparatively greater opportunity to gain ... familiarity [with the specific scientific problems and principles at issue] than an appeals court judge who must read a written transcript or perhaps just those portions to which the parties have referred. ${ }^{31}$

The Court also addressed Sandoz's arguments that "claim construction mostly consists of construing a set of written documents that do not give rise to subsidiary factual disputes" and that it is often difficult to separate "factual" from "legal" questions. ${ }^{32}$ The Court noted even if it could ignore the mandate of FRCP 52(a), it would not find these arguments convincing because appellate courts "have long found it possible to separate factual from legal matters." ${ }^{33}$ Nor was the Court concerned that a clear error requirement for review of subsidiary findings of fact would cause uniformity problems. ${ }^{34}$

The Court also addressed the argument raised by the dissent "that claim construction does not involve any 'factfinding,' or, if it does, claim construction factfinding is akin to the factfinding that underlies our interpretation of statutes. ${ }^{\text {35 }}$ The majority explained that this argument runs afoul of the Supreme Court's decision in Markman, which specifically referenced the "evidentiary underpinnings" of claim construction and courts must sometimes make "credibility judgments" about witnesses during claim construction. ${ }^{36}$ Nor was the majority compelled by the argument that factfinding relating to claim

26. $I d$.

27. Id. at 837 (quoting Pullman-Standard v. Swint, 456 U.S. 273, 287 (1982)).

28. 517 U.S. 370 (1996).

29. Teva Pharm., 135 S. Ct. at 837.

30. Id. at 838 .

31. Id.

32. Id. at 839 .

33. Id.

34. Id.

35. Id. at 840 .

36. Id. (citing Markman v. Westview Instruments, Inc., 517 U.S. 370, 389-90 (1996)). 
construction is akin to the factfinding relating to statutory interpretation, which should compel the conclusion that the Court should apply a de novo review standard. ${ }^{37}$ The Court explained the audiences for statutes and patent claims are decidedly different, as are the parties that consider the relevant facts before Congress enacts a statute or a patent issues. ${ }^{38}$ Accordingly, the Court reasoned "it is not surprising that this Court has never previously compared patent claim construction in any here relevant way to statutory construction." ${ }^{39}$

Under this framework, having decided that subsidiary factual findings made during claim construction should be considered under a "clear error" standard, the Court then undertook to "explain how the rule must be applied in that context." 40 The Court stated that "[a]s all parties agree, when the district court reviews only evidence intrinsic to the patent (the patent claims and specifications, along with the patent's prosecution history), the judge's determination will amount solely to a determination of law, and the court of appeals will review that construction de novo." ${ }^{, 41}$ However, where the district court "look[s] beyond the patent's intrinsic evidence" and "consult[s] extrinsic evidence in order to understand, for example, the background science or the meaning of a term in the relevant art during the relevant time period," the appellate court should apply the clear error standard on review. ${ }^{42}$

The majority opinion concluded by finding that the Federal Circuit erred by not applying the clear error standard when evaluating the district court's findings of fact relating to testimony of expert witnesses about the disputed claim term. ${ }^{43}$ The Court therefore vacated the Federal Circuit's judgment and remanded for further proceedings. ${ }^{44}$

\section{B. Justice Thomas's Dissent Joined by Justice Alito}

In the dissenting opinion authored by Justice Thomas and joined by Justice Alito, the dissenters argued the issue in this case was not whether FRCP 52(a)(6) requires findings of fact to be considered under the clear error standard, but whether claim construction even involves any findings of fact. ${ }^{45}$ The dissenters analogized patents to deeds and statutes, and concluded that "[b]ecause the skilled artisan inquiry in claim construction more closely resembles determinations categorized as 'conclusions of law' than determinations categorized as 'findings of fact," "they "would hold that it falls outside the scope of Rule 52(a)(6) and is

37. Id.

38. Id.

39. Id.

40. Id. (emphasis in original).

41. Id. at 841 .

42. Id.

43. Id. at 842-43.

44. Id. at 843 .

45. Id. at 844 (Thomas, J., dissenting). 
subject to de novo review. " finding that subsidiary determinations by a district court during claim construction are, in actuality, findings of fact. ${ }^{47}$ They further took issue with the majority's characterization of the district court as being the most properlypositioned judicial actor to decide the issues in question relating to claim construction. ${ }^{48}$ The dissenters noted the appellate courts are better suited to ensure uniformity throughout the district courts, and rule-of-law and uniformity considerations outweigh the principle that a district court has "special competence" relating to evaluating testimony of expert witnesses, including live testimony. ${ }^{49}$ Accordingly, the dissenters concluded they "would hold that the Court of Appeals correctly treated the indefiniteness inquiry as a question of law because it depends entirely on claim construction."

\section{Claim Construction in INTER Partes Review: IN RE CUOZZO SPEED TECH., LLC}

Sitting en banc, the Court of Appeals for the Federal Circuit, stated that "broadest reasonable interpretation" is the proper claim construction at the U.S. Patent and Trademark Office ("PTO"), including in post-grant proceedings before the Patent Trial and Appeal Board ("PTAB"). ${ }^{51}$ The en banc court also decided that institution decisions are not reviewable by the Federal Circuit. ${ }^{52}$

Post-grant proceedings before the PTAB have quickly become a very popular forum for patent disputes. Instead of having a district court jury from an unfavorable venue decide the fate of an accused product, many accused infringers are turning to the PTAB to reevaluate the validity of asserted patents. And many post-grant issues, including use of broadest reasonable interpretation and review of institution decisions have been heavily litigated and discussed in the legal press. As a sign of the significance of these issues, the U.S. Supreme Court agreed to hear these two issues by granting certiorari in Cuozzo.$^{53}$ The specific questions at issue are:

1. Whether the court of appeals erred in holding, in IPR proceedings, the PTAB may construe claims to an issued patent according to their broadest reasonable interpretation rather than their plain and ordinary meaning.

2. Whether the court of appeals erred in holding that, even if the PTAB exceeded its statutory authority in instituting an IPR proceeding, the PTAB's

46. Id. at 849 .

47. Id. at 849-50.

48. Id. at 850 .

49. Id. at 850-51.

50. Id. at 852 .

51. In re Cuozzo Speed Techs., LLC, 793 F.3d 1268 (Fed. Cir. 2015), cert. granted, 136 S. Ct. 890 (2016). Judge Newman provided a lengthy dissenting opinion. Id. at 1283-91 (Newman, J., dissenting).

52. Id. at 1268 (majority opinion).

53. See Cuozzo Speed Techs., LLC v. Lee, 136 S. Ct. 890 (2016). 
decision whether to institute an IPR proceeding was judicially unreviewable. ${ }^{54}$

In federal district court patent cases, claim construction is decided based on the Federal Circuit's en banc Phillips v. $A W H$ decision and its progeny. ${ }^{55}$ In stark contrast to that test, the PTO, using its rulemaking authority permitted under the American Invents Act ("AIA") statute, set "broadest reasonable interpretation" as the claim construction test for post-grant proceedings. ${ }^{56}$ Indeed, the AIA statute did not prescribe the test for claim construction in post-grant proceedings, but instead provided the PTO with rulemaking authority for the proceedings. ${ }^{57}$

The PTO has used broadest reasonable construction as the claim construction test for over 100 years and the Federal Circuit approved the PTO's use of that test in a "variety of proceedings, including initial examinations, interferences, and post-grant proceedings such as reissues and reexaminations." 58 This fact played a role in the majority opinion concluding that "Congress implicitly approved the broadest reasonable interpretation standard in enacting the AIA." 59 In short, knowing the PTO's long standing use of the broadest reasonable interpretation test, when Congress gave rulemaking authority to the PTO to determine the claim construction standard, it implicitly approved the broadest reasonable interpretation standard for post-grant proceedings. ${ }^{60}$ Alternatively, the majority opinion applied the well know Chevron analysis and found that the broadest reasonable interpretation was proper. ${ }^{61}$ An example of the reasonableness of the broadest reasonable interpretation standard is that the AIA statute permits postgrant proceedings to be consolidated with other types of PTO proceedings (e.g., reexam) and those other proceedings operate under the broadest reasonable interpretation test. ${ }^{62}$

Turning to the decision regarding review of the institution decision, it is helpful to understand where institution decisions occur in the post-grant process. A post-grant proceeding begins with the filing of a petition challenging the validity of a patent. ${ }^{63}$ Following an optional preliminary response by the patent owner, a panel of three PTAB judges decides, on a challenged claim-by-claim basis, whether to institute a trial. ${ }^{64}$ This institution decision is critical for both the petitioner and patent owner because a denial likely sends the patent and parties back to district court, whereas an institution moves the parties onward through the post-grant discovery process and to the hearing. Either scenario has a profound

54. Id.

55. Phillips v. AWH Corp., 415 F.3d 1303 (Fed. Cir. 2005) (en banc).

56. In re Cuozzo Speed Techs., LLC, 793 F.3d at 1275.

57. Id.

58. Id. at 1276 .

59. Id. at 1278 .

60. Id. at $1277-78$.

61. Id. at 1278-79

62. Id. at 1279 .

63. See 37 C.F.R. $\S 42.200$ (2015).

64. Id. $\S 42.208$. 
impact on a settlement.

In Cuozzo, for certain claims, the PTAB panel instituted based on prior art that the petitioner did not rely on in its petition. ${ }^{65}$ The majority found 35 U.S.C. $\S 314(\mathrm{~d})$ precludes appeal of an institution at any time, including after a final decision from the PTAB ${ }^{66}$ In particular, the Federal Circuit found that "Section 314(d) provides that the decision [whether to institute review] is both 'nonappealable' and 'final,' i.e., not subject to further review." ${ }^{\prime 67}$ The majority opinion also included a lengthy discussion of mandamus relief from institution decisions. ${ }^{68}$ Despite prior decisions finding mandamus relief from institution decisions was not available, the majority noted that "[w]e need not decide whether mandamus to review institution of IPR after a final decision is available in other circumstances." ${ }^{\circ 9}$

The Supreme Court decision in Cuozzo is expected around June 2016. Leading up to that decision, Federal Circuit panels have continued to use the broadest reasonable interpretation for post-grant proceedings. One noteworthy Federal Circuit panel decision issued after the en banc Cuozzo decision discussed the difference between the Phillips and broadest reasonable interpretation standards and how that difference was case dispositive. ${ }^{70}$ Thus, as the Supreme Court wrestles with this issue, it knows at least one case is ongoing where the claim construction standard is more than a theoretical issue.

\section{Means Plus Function Claiming: Williamson V. CitriX OnLine, LLC}

In Williamson v. Citrix Online, $L L C{ }^{71}$ the Federal Circuit, sitting en banc, addressed the standard for determining when a patent claim should be subject to 35 U.S.C. $\S 112$, $\mid 6$ (i.e., a means-plus-function claim). In particular, the court reexamined the multitude of prior Federal Circuit opinions, beginning with Lighting World, Inc. v. Birchwood Lighting, Inc. ${ }^{72}$ which held that there is a "strong" presumption against the application of $\S 112,96$ to claims that do not recite the word "means." "73 Led by Judge Richard Linn, the majority overruled this "strong" presumption in favor of a simple presumption that claims that do not recite the word "means" are not subject to $\S 112$, q 6 . $^{74}$

65. In re Cuozzo Speed Techs., LLC, 793 F.3d at 1272.

66. Id. at 1273 .

67. Id.

68. Id. at $1274-75$.

69. Id.

70. PPC Broadband, Inc. v. Corning Optical Commc'ns RF, LLC, 815 F.3d 734 (Fed. Cir. 2016).

71. 792 F.3d 1339 (Fed. Cir. 2015) (en banc).

72. 382 F.3d 1354, 1358 (Fed. Cir. 2004).

73. Williamson, 792 F.3d 1349.

74. Id. 


\section{A. Background}

Richard A. Williamson is the owner of U.S. Patent No. 6,155,840 ("the ' 840 Patent"), which "describes methods and systems for 'distributed learning' that utilize industry standard computer hardware and software linked by a network to provide . . . a 'virtual classroom' environment."75 On March 22, 2011, Williamson sued Citrix Online, LLC, and others (collectively "Citrix"), in the U.S. District Court for the Central District of California for allegedly infringing all twenty-four claims of the ' 840 Patent by commercializing "various systems and methods of online collaboration.,"76

The district court made two holdings, only the first of which relates to $\S 112$, 9 $6{ }^{77}$ First, the district court held claim 8 , and thus dependent claims $9-16,{ }^{78}$ was invalid, because claim 8's "distributed learning control module" limitation was subject to $\S 112$, ๆ 6 and the ' 840 Patent's specification "failed to disclose the necessary algorithms for performing all of the claimed functions." ${ }^{.79}$ Second, and of lesser significance to this Article, the district court held that claims 1 and 17 "require[d] 'a pictorial map illustrating an at least partially virtual space in which participants can interact, and that identifie[d] the presenter(s) and the audience member(s) by their locations on the map," "and thus Citrix's accused products did not infringe claims 1 and $17 .^{80}$ Williamson appealed both rulings. ${ }^{81}$

\section{B. Analysis}

On appeal, the Federal Circuit addressed two issues, only the first of which was, in part, reviewed en banc: (1) whether the district court erred in finding that claim 8's "distributed learning control module" limitation was subject to $\S 112$, I 6 and invalid in view of a deficient patent specification; and (2) whether the district court erred in its construction of claims 1 and 17 by importing a "pictorial map" limitation into the claim. The Federal Circuit reviewed both of these issues de novo. ${ }^{82}$

1. Did the District Court Err in Finding "Distributed Learning Control Module" Was Subject to $\S 112$, थ 6 and Invalid in View of the Deficient Specification? - No. ${ }^{83}$ The Federal Circuit approached this question in two

75. Id. at 1343 .

76. Id. at 1345 .

77. Id.

78. See Alcon Research, Ltd. v. Apotex Inc., 687 F.3d 1362, 1367 (Fed. Cir. 2012) ("[B]ecause a dependent claim narrows the [independent] claim from which it depends, it must 'incoporate ... all the limitations of the claim to which it refers."' (quoting 35 U.S.C. § 112, ๆ 4 (2012))).

79. Williamson, 792 F.3d at 1345.

80. Id.

81. Id.

82. Id. at 1346.

83. Id. at 1354. 
steps ${ }^{84}$ First, the court determined whether claim 8 's "distributed learning control module" was in fact subject to $\S 112$, ๆ $6 .{ }^{85}$ After finding it was, the court next determined whether the ' 840 Patent's specification provided sufficient disclosure to support the claim - a question which it answered in the negative. ${ }^{86}$

In the only en banc portion of its opinion, the majority began its analysis by overruling the prior $\S 112$, 6 standard embraced by Lighting World, Inc., and concluded that when a claim term lacks the word "means," there is a mere presumption $\S 112$, ๆ 6 will not apply. ${ }^{87}$ Under Lighting World, Inc., there was a strong presumption that a claim lacking the word "means" was not subject to $\S$ $112, \boldsymbol{\oplus} 6 .^{88}$

To reach this conclusion, the court started with the language of $\S 112$, 6 , which governs means-plus-function patent claims and states:

An element in a claim for a combination may be expressed as a means or step for performing a specified function without the recital of structure, material, or acts in support thereof, and such claim shall be construed to cover the corresponding structure, material, or acts described in the specification and equivalents thereof. ${ }^{89}$

According to the court, "[i]n enacting this provision, Congress struck a balance in allowing patentees to express a claim limitation by reciting a function to be performed rather than by reciting structure for performing that function, while placing specific constraints on how such a limitation is to be construed." ${ }^{.90}$ In view of the statute, and the congressional intent behind it, the court recognized that the "presence or absence of the word "means" is important in determining whether $\S 112$, I 6 applies-however, the court explained, there is no need to elevate "form over substance," which is exactly what the three-judge Federal Circuit panel did in its 2004 opinion of Lighting World, Inc., derailing the proper presumption that should be imposed under $\S 112, \uparrow 6 .{ }^{91}$

The court explained the heightened $\S 112$, 96 presumption laid out in Lighting World, Inc. "shifted the balance struck by Congress in passing $\S 112$, para. 6 and has resulted in a proliferation of functional claiming untethered to $\S$ 112 , para. 6 and free of the strictures set forth in the statute." ${ }^{.92}$ As such, the Lighting World, Inc. decision was flawed. ${ }^{93}$ In full, the court set forth the following standard for $\S 112$, 6 , which states:

84. Id. at 1347-49, 1351-54.

85. Id. at $1347-49$.

86. Id. at $1351-54$

87. Id. at 1349.

88. Id. at 1350 .

89. Id. at 1347 (quoting 35 U.S.C. § 112, ๆ 6 (2012)).

90. Id.

91. Id. at 1348 .

92. Id. at 1349 .

93. Id. 
The standard is whether the words of the claim are understood by persons of ordinary skill in the art to have a sufficiently definite meaning as the name for structure. When a claim term lacks the word "means," the presumption can be overcome and $\S 112$, para. 6 will apply if the challenger demonstrates that the claim term fails to recited sufficiently definite structure or else recites function without reciting sufficient structure for performing that function. ${ }^{94}$

Under the correct $\S 112$, $\mid 6$ standard, the court then analyzed whether claim 8 's "distributed learning control module" should be governed by $\S 112, \uparrow 6$, as found by the district court. ${ }^{95}$ Williamson argued $\S 112$, 6 should not apply because the claim should be viewed in full, and the district court "wrongly focused its analysis on the word "module." $" 96$ In response, Citrix argued that application of $\S 112, \boldsymbol{6} 6$ is appropriate, because Williamson "merely replace[d] the term 'means' with 'nonce' word 'module,' thereby connoting a generic 'black box' for performing the recited ... functions." $" 97$

In agreeing with Citrix, the court explained "module," like other nonce terms (e.g., "mechanism," "element," "device", etc.), "does not provide any indication of structure." ${ }^{\circ 8}$ Nor, the court reasoned, does the prefix "distributed learning control" impart structure into the term "module," because the specification "fail[ed] to impart any structural significance to the term." testimony presented could not cure the deficiency because "the fact that one of skill in the art could program a computer to perform the recited functions cannot create structure where none otherwise is disclosed." 100

As a means-plus-function claim (i.e., subject to $\S 112, \uparrow 6$ ), the court next addressed "whether the specification disclose[d] sufficient structure that correspond[ed] to the claimed function." function of the claimed "distributed learning control module"-one of three functions associated with the claim-the court found the specification was lacking because it failed to disclose an algorithm for performing the "coordinating" function. ${ }^{102}$ Under Federal Circuit law, where a "special purpose computer" is required (i.e., a computer programmed to perform particular functions) to implement the claimed function, the specification must provide an algorithm, which can be "expressed as a mathematical formula, in prose, or as a flow chart, or in any other manner that provides sufficient structure." ${ }^{, 103}$ The ' 840

94. Id. (internal citation and quotations omitted).

95. Id. at 1349-51.

96. Id. at 1349.

97. Id. at 1350.

98. Id.

99. Id. at 1351.

100. Id.

101. Id.

102. Id. at 1352 .

103. Id. 
Patent specification simply failed to disclose such an algorithm, thus rendering claim eight invalid. ${ }^{104}$

2. Did the District Court Err in Its Construction of Claims One and Seventeen by Importing a "Pictorial Map" Limitation into the Claims?-Yes. ${ }^{105}$ Agreeing with Williamson, the court found the district court erred in construing certain terms in claims 1 and 17 as requiring a "pictorial map" (i.e., a map that identifies the location of the participants), because the claim language contained no such limitation and the intrinsic record was devoid of any indication that the applicant intended the claims to be so limited. ${ }^{106}$ In so holding, the court vacated the district court's judgment of noninfringement of these and related claims. ${ }^{107}$

\section{Additional Opinions}

1. Judge Reyna, Concurring in Part, Dissenting in Part, and Expressing Additional Views.- In a partial dissent, Judge Reyna disagreed with the majority's claim construction ruling because, in his view, "[t]he repeated mention of the classroom metaphor within the context of the invention and the importance of a visually depicted virtual classroom in the prosecution history indicate that the 'graphical display representative of a classroom' terms require a visually depicted virtual classroom." 108 And while agreeing with the majority's ultimate conclusion, Judge Reyna expressed concern that any presumption attached to $\S 112$, $\mid 6$ and use of the term "means" may be improperly elevating form over substance, because many terms other than "means" fail to recite sufficient structure for performing recited functions. ${ }^{109}$

2. Judge Newman, Dissenting from the En Banc Panel's Majority Opinion.-Dissenting from the majority's en banc ruling on $\S 112$, ๆ 6 , Judge Newman rebuked the majority's overruling of "dozens of cases" and departure from the clear language of $\S 112, \uparrow 6 .{ }^{110}$ In his view, this ruling would serve only to promote uncertainty in patent law and, thus, excessive litigation and a disincentive to patent-based innovation. ${ }^{111}$

\section{Post-Expiration Roy ALTIES: KIMBLE V. MARVEL ENTERTAINMENT, LLC}

The Supreme Court's decision in Kimble v. Marvel Entertainment, LLC addresses a straightforward, simple question - are patent royalites owed for sales made after a patent expires. ${ }^{112}$ The unequivocal answer is absolutely not, based

104. Id. at 1353 .

105. Id. at $1346-47$.

106. $I d$.

107. Id. at 1347 .

108. Id. at 1356 .

109. Id. at $1356-58$.

110. Id. at $1358-63$.

111. Id.

112. Kimble v. Marvel Entm't, LLC, 135 S. Ct. 2401 (2015). 
on the Supreme Court's prior precedent in Brulotte v. Thys Co. ${ }^{113}$ However, in this decision, the Supreme Court went to great lengths to outline how parties negotiating a patent agreement could circumvent Brulotte and Kimble.

The agreement in dispute was the result of a patent litigation settlement between the patent owner, Stephen Kimble, and accused infringer, Marvel Entertainment. ${ }^{114}$ The accused infringing product was a toy called a Web Blaster that allows children to imitate Spider-Man. ${ }^{115}$ Settling the dispute, the parties may have realized that a Spider-Man toy could be popular well past the expiration of the agreement. And the parties did not set an end date for royalty payments to end for sales of accused products. ${ }^{116}$ Specifically, the settlement agreement included Marvel obtaining the patent-in-suit for a lump sum patent of about $\$ 500,000$ and an ongoing $3 \%$ royalty on future sales of the Web Blaster and similar products. ${ }^{117}$

Apparently, neither Kimble nor Marvel were aware of Brulotte before signing the settlement agreement. ${ }^{118}$ Shortly before expiration of the patent-in-suit, Marvel learned of Brulotte and filed a declaratory judgment action in the United States District Court for the District of Arizona against Kimble seeking a declaration that royalites were not owed after expiration of the patent. ${ }^{119}$ Both the district court and Court of Appeals for the Ninth Circuit found royalties were not owed post expiration, but the Supreme Court quoted the Ninth Circuit's complaint that the Brulotte rule "is counterintuitive and its rationale is arguably unconvincing." $" 120$

The majority grounded its decision on long standing patent policy and cases that permit the public to practice patent rights after expiration of a patent. ${ }^{121}$ Indeed, this is part of a fundamental quid pro quo of the U.S. patent system; the government provides a limited monopoly to the owner of patent rights in exchange for the patent owner disclosing the invention to the public and permitting the invention to be practiced after the patent expires.

In addition, stare decisis played a large role in the decision. And because the Brulotte rule rests on an interpretation of a statute, 35 U.S.C. $§ 154$, stare decisis "carries enhanced force" and "critics of [the Court's] ruling can take their objections across the street, and Congress can correct any mistake it sees. ${ }^{122}$ Moreover, the majority noted that since Brulotte, Congress amended the patent laws many times and, in the process, specifically looked at amending $\S 154$ in the

113. 379 U.S. 29 (1964).

114. Kimble, 135 S. Ct. at 2406.

115. Id.

116. Id.

117. $I d$.

118. Id.

119. Id.

120. Id. (quoting Kimble v. Marvel Enters., Inc., 727 F.3d 856, 857 (9th Cir. 2013), aff'd, 135

S. Ct. 2401 (2015)).

121. Id. at $2406-07$.

122. Id. at 2409 . 
manner suggested Kimble, but declined to do so. ${ }^{123}$ In a similar vein, in response to economic analysis criticizing the Brulotte rule, the majority did not take issue with Kimble's economic analysis, but once again pointed to Congress as the proper forum to change the law, if necessary. ${ }^{124}$

The simple application of the Brulotte rule also compelled following stare decisis, as

[t]he decision is simplicity itself to apply. A court need only ask whether a licensing agreement provides royalties for post-expiration use of a patent. If not, no problem; if so, no dice. Brulotte's ease of use appears in still sharper relief when compared to Kimble's proposed alternative. Recall that he wants courts to employ antitrust law's rule of reason to identify and invalidate those post-expiration royalty clauses with anticompetitive consequences. ${ }^{125}$

As a sign the majority possibly agreed that the Brulotte rule is not fundamentally sound, it laid out the following ways parties negotiating a patent agreement can circumvent Brulotte and Kimble, by including language such as

- "licensee to defer payments for preexpiration use of a patent into the post-expiration period"

- "royalties may run until the latest-running patent covered in the parties' agreement expires"

- "post-expiration royalties are allowable so long as tied to a non-patent right-even when closely related to a patent."

- "business arrangements other than royalties-all kinds of joint ventures, for example - that enable parties to share the risks and rewards of commercializing an invention." 126

The majority opinion is grounded on two fundamental points. First, this issue has been, and continues to be, available for Congress to address in its continuous work on patent statutes. To date, Congress has not done so. Second, parties with knowledge of Brulotte and Kimble can achieve their business objectives in a variety of ways, some explicitly laid out in the opinion, despite the encumbrance of not collecting royalties for post-expiration sales.

V. Reasonable Royalty PATENT InFRINGEMENT Damages For STANDARD ESSENTIAL PATENTS: COMMONWEALTH SCIENTIFIC \& INDUSTRIAL RESEARCH ORGANISATION V. CISCO SYSTEMS, INC.

In only the fifth installment ${ }^{127}$ of the Federal Circuit's damages jurisprudence

123. Id.

124. Id. at 2413-14.

125. Id. at 2411.

126. Id. at 2408.

127. See JVC Kenwood Corp. v. Nero, Inc., 797 F.3d 1039 (Fed. Cir. 2015); Ericsson, Inc. v. D-Link Sys., Inc., 773 F.3d 1201 (Fed. Cir. 2014); Apple Inc. v. Motorola, Inc., 757 F.3d 1286 (Fed. Cir. 2014); Microsoft Corp. v. Motorola, Inc., 564 Fed. App’x 586 (Fed. Cir. 2014). 
relating to standard essential patents ("SEPs"), the Federal Circuit, in Commonwealth Scientific \& Industrial Research Organisation v. Cisco Systems, Inc., ${ }^{128}$ clarified what litigants and courts can appropriately consider in determining reasonable royalty damages for infringement of SEPs. In a unanimous opinion authored by Chief Judge Sharon Prost, the Federal Circuit made two significant holdings: (1) reliance on comparable license valuations, as opposed to the smallest salable patent-practicing unit principle, is consistent with apportionment principles; and (2) SEP reasonable royalty damages methodologies, even if not RAND-encumbered, must account for and separate the value added by their SEP status. ${ }^{129}$

\section{A. Background}

The case started when Commonwealth Scientific and Industrial Research Organisation ("CSIRO") accused Cisco Systems, Inc. ("Cisco") of infringement of U.S. Patent No. 5,487,069 ("the "069 Patent"). ${ }^{130}$ As the research arm of the Australian federal government, CSIRO "set out to devise faster and more reliable wireless local area network technology"-efforts that resulted in the '069 Patent, which issued in $1996 .{ }^{131}$ The technology disclosed in the "069 Patent was so useful that, in 1997, the Institute of Electrical and Electronics Engineers ("IEEE") included it in the 802.11 wireless standard (think Wi-Fi). ${ }^{132}$ Although CSIRO initially assured the IEEE it would license the " 069 Patent on reasonable and nondiscriminatory ("RAND") terms, CSIRO refused to do so for later versions of the 802.11 standard. ${ }^{133}$

1. Setting the Scene for SEPs.-At this point, it is appropriate to digress from the case to provide more background on the realm of SEPs. The IEEE is what is known as a standards development organization ("SDO"). ${ }^{134}$ SDOs adopt and publish standards, to which device manufacturers generally adhere, to "ensure[] interoperability among compliant devices." ${ }^{~ 135}$ Think, for example, of wireless internet. Wireless internet is controlled by the 802.11 standard, under the Wi-Fi brand, such that every 802.11-compliant device (e.g., a laptop) knows "what frequency to search for the wireless signal, what messages to send to the network to set up a connection, and how to interpret the messages sent from the network." ${ }^{\prime 136}$ Establishing a ubiquitous standard for widely used technology, like wireless internet, is necessary in such applications given the "multitude of

128. 809 F.3d 1295 (Fed. Cir. 2015), petition for cert. filed.

129. Id. at 1297 . The court made a third factual-based holding, which is less important to subsequent SEP damages case law. See infra Part II.B.3

130. Commonwealth Sci., 809 F.3d at 1297.

131. Id.

132. Id. at $1297-98$.

133. Id. at 1298 .

134. Ericsson, Inc. v. D-Link Sys., Inc., 773 F.3d 1201, 1208 (Fed. Cir. 2014).

135. Id.

136. Id. 
devices, device designers, and manufacturers ... to ensure compatibility among all these different devices." ${ }^{\prime 137}$ Put simply, the 802.11 standard is the reason laptop users can go to any coffee shop in the country and know their laptop will be able to connect to the wireless internet. ${ }^{138}$

These SDO standards are created through a complicated vetting process involving the adoption of technology, which is often covered by patents. ${ }^{139}$ Once a patent is included in a standard, the patent becomes a SEP. ${ }^{140}$ Because a standard-compliant device necessarily infringes the relevant SEPs, some SDOs ask that SEP owners "pledge that they will grant licenses to an unrestricted number of applicants on 'reasonable, and nondiscriminatory' ('RAND') terms" to prevent SEP owners from inhibiting the spread of the standard (e.g., by threatening costly patent infringement lawsuits). ${ }^{141}$ Digression concluded.

2. Prior '069 Patent Licensing Negotiations.-There were three past licensing negotiations related to the "069 Patent relevant to this case: (1) the technology license agreement ("TLA") with Radiata; (2) the CSIRO-developed Rate Card; and (3) Cisco's informal royalty rate suggestion. As for the TLA, shortly after the '069 Patent issued in 1996, a number of the scientists involved in the technology research effort formed Radiata, a company founded to commercialize the '069 Patent. ${ }^{142}$ Thereafter, Radiata entered into the TLA with CSIRO to license the '069 Patent for specific Radiata chips at rates based on a percentage of the product price. ${ }^{143}$ In 2000, however, Cisco acquired Radiata and, through various amendments of the TLA, took Radiata's place as the '069 Patent licensee. ${ }^{144}$

Recognizing the potential for greater revenues, CSIRO developed what it called the "Rate Card," which was a form license it envisioned offering to potential licensees of the '069 Patent. ${ }^{145}$ The Rate Card used flat dollar amount rates, as opposed to the percentage rates used in the TLA. ${ }^{146}$ In 2004, CSIRO approached Cisco about adopting the Rate Card rates, which were higher than the TLA rates Cisco was paying, for a license of the '069 Patent that covered chips not under the TLA. ${ }^{147}$ Cisco ultimately declined, although the record reflected that

137. $I d$.

138. Id.

139. Id. at 1209.

140. Id.

141. $I d$.

142. Commonwealth Sci. \& Indus. Research Org. v. Cisco Sys., Inc., 809 F.3d 1295, 1298 (Fed. Cir. 2015).

143. Id.

144. Id.

145. Id.

146. Id.

147. Commonwealth Sci. \& Indus. Research Orga. v. Cisco Systems, Inc., No. 6:11-cv-343, 2014 WL 3805817, *9 n.10 (July 23, 2014) ("It is not contested that any Linksys or Cisco products containing chips licensed under the TLA are not accused in this case, since a royalty has already been paid on them.”), vacated, 809 F.3d 1295 (Fed. Cir. 2015). 
Cisco's Vice President of Intellectual Property “informally suggested to CSIRO that a $\$ 0.90$ per unit rate may be more appropriate." ${ }^{148}$ CSIRO and Cisco failed to come to an agreement, and CSIRO never executed any licenses under the Rate Card ${ }^{149}$ Cisco, however, paid TLA royalties to CSIRO until 2007, when it stopped using Radiata-based chips in its products, although Cisco apparently never stopped selling '069 Patent-embodied products. ${ }^{150}$

3. Lower Court Litigation.-In 2011, CSIRO sued Cisco for patent infringement of the "069 Patent in the Eastern District of Texas. ${ }^{151}$ After Cisco stipulated to infringement and validity, the district court held a four-day bench trial in which it adopted neither party's damages methodology and concluded Cisco owed CSIRO $\$ 16,243,067 .{ }^{152}$

At trial, the parties predictably presented competing damages methodologies. ${ }^{153}$ CSIRO proposed a royalty rate of $\$ 1.35$ to $\$ 2.25$ per end unit sold, which it reached by reasoning the difference in price of 802.11-compliant products that practice the " 069 Patent and those that do not is attributable to the value of the '069 Patent. ${ }^{154} \mathrm{Cisco}$, on the other hand, proposed a royalty rate of $\$ 0.03$ to $\$ 0.37$ per end unit sold, which it reached by relying on the TLA. ${ }^{155}$

In faulting both parties' methodologies, the district court explained the correct damages methodology under these facts should be based on the 2004 Rate Card and the informal rate suggestion made by Cisco's Vice President of Intellectual Property. ${ }^{156}$ The district court also explained because the '069 Patent was not RAND-encumbered, there was no need to alter the reasonable royalty analysis from other non-SEP patent reasonable royalty analyses. ${ }^{157}$ After considering all the Georgia-Pacific factors, the court reasoned an award of $\$ 16,243,067$ was appropriate. ${ }^{158}$ Cisco appealed. ${ }^{159}$

\section{B. Analysis}

On appeal, Cisco presented two independent legal reasons for reversal: (1) "the district court erred in not beginning its damages analysis with the wireless chip, which it found to be the smallest salable patent-practicing unit;" and (2) "the district court did not adjust the Georgia-Pacific factors to account for the asserted

148. Commonwealth Sci., 809 F.3d at 1299.

149. Id.

150. Id.

151. Id.

152. Id. at 1300 .

153. Id. at 1299.

154. Id.

155. Id.

156. Id. at 1300 .

157. Id.

158. Id.

159. Id. 
patent being essential to the 802.11 standard." ${ }^{160}$ Cisco also argued the district court made a clearly erroneous finding of fact because it did not credit Cisco's TLA evidence. ${ }^{161}$

1. Did the District Court Err for Not Beginning Its Damages Analysis with the Smallest Salable Patent-Practicing Unit? - No. ${ }^{162}$ The Federal Circuit concluded the "district court did not violate apportionment principles in employing a damages model that took account of the parties' informal negotiations with respect to the end product." ${ }^{163}$ Under 35 U.S.C. § 284, patent infringement damages in the context of multi-component products must follow what is known as the apportionment principle. ${ }^{164}$ The apportionment principle mandates that "all expert damages opinions must separate the value of the allegedly infringing features from the value of all other features." ${ }^{65}$ The underlying rationale for the apportionment principle comes from the need to protect litigants from the "inherent imprecision in patent valuation" by "ensur[ing] that the testimony presented-using whatever methodology-is sufficiently reliable to support a damages award." 166

Recognizing the apportionment principle allows for "more than one reliable method for estimating a reasonable royalty," the court then analyzed acceptable apportionment models. ${ }^{167}$ First, the court endorsed the long-accepted smallest salable patent-practicing unit ("SSU") principle-which Cisco contended should be required in every reasonable royalty analysis - as an acceptable, albeit inapplicable, apportionment model. ${ }^{168}$ Under the SSU principle, "where a damages model apportions from a royalty base, the model should use the smallest salable patent-practicing unit as the base" (i.e., not the entire product). ${ }^{169}$ The court provided two justifications for the SSU principle: (1) "[w]here small elements of multi-component products are accused of infringement, calculating a royalty on the entire product carries a considerable risk that the patentee will be improperly compensated for non-infringing components of that product"; and (2) "disclosure of the end product's total revenue cannot help but skew the damages horizon for the jury, regardless of the contribution of the patented component to this revenue." 170 The court, however, explained the SSU principle was inapplicable to these facts because "the district court did not apportion from a royalty base at all," but instead "began with the parties' negotiations." 171

160. Id. at $1300-01$.

161. Id.

162. Id. at 1304.

163. Id.

164. Id. at 1301.

165. Id.

166. Id.

167. Id. (quoting Apple Inc. v. Motorola, Inc., 757 F.3d 1286, 1315 (Fed. Cir. 2014)).

168. Id. at 1302 .

169. Id.

170. Id. (internal quotations and citations omitted).

171. Id. 
Second, the court approved of using comparable licenses as a valid apportionment model. ${ }^{172}$ Under a comparable license model, rates from comparable licenses are used as a starting point and then adjusted for "differences in the technologies and economic circumstances of the contracting parties."173 Such a model, the court explained, "is typically reliable because the parties are constrained by the market's actual valuation of the patent." ${ }^{\prime 74}$ Thus, because negotiations between Cisco and CSIRO were precisely over the value of the '069 Patent, the court reasoned this comparable license starting point already builds in apportionment and the SSU principle is unnecessary. ${ }^{175}$

2. Did the District Court Err by Not Adjusting the Georgia-Pacific Factors to Account for the SEP Status of the Patent?-Yes. ${ }^{176}$ The district court erred under Ericsson "because it failed to account for any extra value accruing to the "069 Patent from the fact that it is essential to the 802.11 standard."177 Specifically, the district court failed to account for the added value to the " 069 Patent caused by its inclusion in the 802.11 standard by analyzing GeorgiaPacific factors eight, nine, and ten ${ }^{178}$ - factors which Ericsson calls out as irrelevant in cases involving SEPs. ${ }^{179}$ Indeed, the court explained under Ericsson, that SEPs give rise to two important apportionment issues: (1) "the patented feature must be apportioned from all of the unpatented features reflected in the standard"; and (2) "the patentee's royalty must be premised on the value of the patented feature, not any value added by the standard's adoption of the patented technology." $" 180$

In arguing the district court was correct in its analysis, CSIRO argued the principles identified in Ericsson were inapplicable because such principles are only relevant to RAND-encumbered patents. ${ }^{181}$ The court dismissed CSIRO's argument for two reasons: (1) CSIRO's argument was based on an improper reading of Ericsson, which explicitly held that "the adjustments to the GeorgiaPacific factors apply equally to RAND-encumbered patents and SEPS"; and (2) if the court failed to recognize these principles in the context of non-RAND encumbered patents, then "patentees would receive all of the benefit created by standardization - benefit that would otherwise flow to consumers and businesses

172. Id. at 1303 .

173. Id.

174. Id.

175. Id.

176. Id. at 1304 .

177. Id.

178. Georgia-Pacific factor eight relates to " $[\mathrm{t}]$ he established profitability of the product made under the patent; its commercial success; and its current popularity." Id. at 1305 (quoting GeorgiaPacific Corp. v. U.S. Plywood Corp., 318 F. Supp. 1116, 1120 (S.D.N.Y. 1970)). Georgia-Pacific factors 9 and 10 relate to the "advantages of the patented invention." Id.

179. Id.

180. Id. at 1304 (quoting Ericsson, Inc. v. D-Link Sys, Inc., 773 F.3d 1201, 1232 (Fed. Cir. 2014))

181. Id. 
practicing the standard." 182 The court went on to explain, on remand, that the district court should also account for the possibility that CSIRO's licensing rate negotiations (e.g., the Rate Card rates) could have been impacted by the ' 069 Patent's adoption in the 802.11 standard. $^{183}$

3. Did the District Court Clearly Err by Not Crediting the TLA Evidence?-Yes. ${ }^{184}$ Under a deferential standard of review, the court found "clear error in at least three of the district court's reasons for rejecting the TLA" in its damages methodology. ${ }^{185}$ First, the court found clear error in the district court's rationale that the TLA was untimely, having been signed approximately five years prior to the hypothetical negotiation date at issue. ${ }^{186}$ The court explained although the original TLA was finalized five years prior to the hypothetical negotiation dates, the district court ignored the fact the TLA was twice amended about the time the hypothetical negotiations would have taken place. ${ }^{187}$ Second, the court found clear error in the district court's rationale that the TLA was not evidence of arm's length negotiations because Radiata, the original TLA licensee, was "founded by three Australian individuals on CSIRO's campus." 188 Again, however, the court explained the district court ignored the TLA amendments, which were executed after Cisco acquired Radiata, thus eliminating any "special relationship" that may have once existed with CSIRO ${ }^{189}$ Finally, the court found clear error with the district court's rationale that the TLA was flawed because it used "chip prices as the royalty base" - a rationale in direct contradiction to "Ericsson's holding that a license may not be excluded solely because of its chosen royalty base." ${ }^{, 190}$ In view of these flaws, the court remanded the issue to the district court for reevaluation consistent with its analysis. ${ }^{191}$

\section{The Future of SEP Infringement Damages Jurisprudence}

How the Federal Circuit's decision in Commonwealth Scientific \& Industrial Research Organisation will affect subsequent patent infringement damages cases involving SEPs remains unclear. A number of commentators, however, have expressed skepticism with parts of the Federal Circuit's opinion. For example, Professor Thomas F. Cotter, a respected patent remedies expert, disagreed with the Federal Circuit's second holding that "damages for the infringement of an SEP should not reflect the additional value resulting from standardization." ${ }^{192}$ In

182. Id. at $1304-05$.

183. Id. at $1305-06$.

184. Id. at 1306.

185. Id.

186. Id.

187. Id.

188. Id.

189. Id. at 1306-07.

190. Id. at 1307.

191. Id.

192. Thomas F. Cotter, Damages Issues in CSIRO v. Cisco, ComP. PAt. Remedies (Dec. 3, 
particular, Professor Cotter explained that "[a] technology adopted into a standard necessarily is more valuable to users than one that [is not]." ${ }^{.193}$ Professor Jorge L. Contreras, on the other hand, proposed the Federal Circuit's second holding implies there is no "difference in the royalty payable with respect to a RANDencumbered SEP and the royalty payable with respect to an unencumbered SEP, $"{ }^{194}$ which may be problematic.

\section{ENHANCED Damages: HaLO ELECTRONICS, INC. $V$. PULSE ELECTRONICS, INC. AND STRYKER CORP. V. ZIMMER, INC.}

This section and the one following (which addresses design patent issues in the Apple v. Samsung saga) discuss matters at the U.S. Supreme Court taking place after September 30, 2015, which would otherwise be the terminal date for the subject matter of this Article. Given the mouthwatering excitement these forthcoming Supreme Court matters generate though, the authors could not resist the opportunity to at least preview them.

You are probably pondering, "What has caused such anticipation?" Well, the first preview section discusses how the Supreme Court will soon address the enhanced damages section of the Patent Act: "[T] he court may increase the damages up to three times the amount found or assessed." 195 These days, for $\S$ 284, the Federal Circuit uses a two-part test for determining entitlement to such damages. ${ }^{196}$ The Court will decide the propriety of that test as it hears oral argument on February 23, 2016, in the consolidated cases of Halo Electronics, Inc. v. Pulse Electronics, Inc. and Stryker Corporation v. Zimmer, Inc. ${ }^{197}$ The subsections that follow provide a brief procedural history and note some key arguments that should bear on the Supreme Court's forthcoming decision.

\section{A. Procedural History}

The Supreme Court will address the two-part Federal Circuit test, which applies "a two-prong analysis entailing an objective and a subjective inquiry." 198 This test is as follows:

2015), http://comparativepatentremedies.blogspot.com/2015/12/damages-issues-in-csiro-vcisco.html [https://perma.cc/8BZ8-FCAL].

193. Id.

194. Jorge L. Contreras, CSIRO v. Cisco: The Covergence of RAND and Non-RAND Royalties for Standards-Essential Patents, PATENTLY-O (Dec. 7, 2015), http://patentlyo.com/patent/ 015/12/convergence-royalties-standards.html [https://perma.cc/QMQ9-RLUC].

195. 35 U.S.C. $\$ 284$ (2012).

196. See In re Seagate Tech., LLC, 497 F.3d 1360, 1371 (Fed. Cir. 2007).

197. See Granted \& Noted Listed: Cases for Argument in October Term 2015, Sup. CT. U.S., http://www.supremecourt.gov/orders/15grantednotedlist.pdf [https://perma.cc/23ZZ-LY6H] (last updated May 19, 2016).

198. Halo Elecs., Inc. v. Pulse Elecs., Inc., 769 F.3d 1371, 1381-82 (Fed. Cir. 2014), petition for reh'g en banc denied, 780 F.3d 1357 (Fed. Cir. 2015), cert. denied, 136 S. Ct. 236 (2015). 
First, "a patentee must show by clear and convincing evidence that the infringer acted despite an objectively high likelihood that its actions constituted infringement of a valid patent. . . Second, if the "threshold objective standard is satisfied, the patentee must also demonstrate that this objectively-defined risk ... was either known or so obvious that it should have been known to the accused infringer."199

In casual terms, this test is often referred to as the "Seagate test."

In both Halo and Stryker, the Federal Circuit ruled in favor of the accused infringer based on the objective prong. In Halo, the court ruled that "although Pulse [the accused infringer] was ultimately unsuccessful in challenging the validity of the Halo patents, Pulse did raise a substantial question as to the obviousness of the Halo patents. ${ }^{" 200}$ Likewise, in Stryker, the court pointed out how "[a]n objective assessment of the case shows that Zimmer presented reasonable defenses to all of the asserted claims of Stryker's patents. ${ }^{201}$ In short, the ability of each accused infringer to develop a reasonable defense saved the day.

The Federal Circuit denied both patentees' efforts to obtain an en banc rehearing. ${ }^{202}$ As a result, in June 2015, the patentee in each case (Halo in one, and Stryker in the other) petitioned the Supreme Court for a Writ of Certiorari. The Court consolidated these cases because each presented a similar, primary issue:

Whether the Federal Circuit erred by applying a rigid, two-part test for enhancing patent infringement damages under 35 U.S.C. § 284, that is the same as the rigid, two-part test this Court rejected last term in Octane Fitness, LLC v. ICON Health \& Fitness, Inc., 134 S. Ct. 1749 (2014) for imposing attorney fees under the similarly-worded 35 U.S.C. $\S 285 .{ }^{203}$

Has the Federal Circuit improperly abrogated the plain meaning of 35 U.S.C. $\S 284$ by forbidding any award of enhanced damages unless there is a finding of willfulness under a rigid, two-part test, when this Court recently rejected an analogous framework imposed on 35 U.S.C. $\$ 285$, the statute providing for attorneys' fee awards in exceptional cases? ${ }^{204}$

199. Id. at 1382 .

200. Id. Although Pulse Electronics, Inc. and Pulse Electronics Corporation are both Respondents, this Section will refer to these Respondents collectively as "Pulse."

201. Stryker Corp. v. Zimmer, Inc., 782 F.3d 649, 661 (Fed. Cir. 2014), cert. granted in part, 136 S. Ct. 356 (2015).

202. See Halo Elecs., 780 F.3d 1357 (Fed. Cir. 2014); Stryker Corp. v. Zimmer, Inc., 596 Fed. App'x. 924 (Fed. Cir.), cert. granted in part, 136 S. Ct. 356 (2015).

203. Petition for Writ of Certiorari, at i, Halo Elecs., Inc. v. Pulse Elecs., Inc., No. 14-1513 (U.S. cert granted Oct. 5, 2015).

204. Petition for Writ of Certiorari, at i, Stryker Corp. v. Zimmer, Inc., No. 14-1520 (U.S. cert. granted Oct. 19, 2015) [hereinafter Stryker Petition]. 


\section{B. Instructiveness of Earlier Patent Act Language}

Petitioners and Respondents - to no one's surprise-believe history is on their side. Looking back in time, the Patent Act of 1836 provided for enhanced damages, just as modern law does today: "[I]t shall be in the power of the court to render judgment for any sum above the amount found by such verdict as the actual damages sustained ... according to the circumstances of the case. ${ }^{, 205}$ How courts interpreted this language over the next century, leading up to the Patent Act of 1952, depends on which side you ask.

On the one hand, how might Petitioners view the 1836 language? They trumpet the Supreme Court's Seymour v. McCormick, which reasoned that this enhanced damages provision stemmed from the fact that "[e]xperience had shown the very great injustice of a horizontal rule equally affecting all cases, without regard to their peculiar merits." 206 That is, "[t]he defendant who acted in ignorance or good faith, claiming under a junior patent, was made liable to the same penalty with the wanton and malicious pirate." ${ }^{207}$ According to Petitioners, by addressing the "peculiar merits," courts could handle each accused infringer as an individual, given culpability among such infringers varied from case to case. In the decades that followed, courts applied this individualized approach, aw arding enhanced damages based on conduct ranging from "malice or bad faith" to mere carelessness. ${ }^{208}$

On the other hand, how does Respondents' perspective shape up? Well, they thump Seymour also, reading that case for the lesson that "a jury may inflict vindictive or exemplary damages" only "where the injury is wanton or malicious." 209 After Seymour, myriad circuit court cases articulated similar standards that ranged from "wanton, deliberate, and willful," to "flagrant," to "intentional." 210 Like Petitioners, Respondents brandish their own catalog of favorable cases that followed Seymour, albeit articulating canons contrary to Petitioners' preferred precedents. What is more, subsequent Supreme Court cases Aro Manufacturing Co. v. Convertible Top Replacement Co. and Dowling v. United States echoed standards for enhanced damages similar to the "wanton and

205. Patent Act of 1836,5 Stat. 117.

206. 57 U.S. 480, 488 (1854); Petitioner's Opening Brief, Halo Elecs., Inc. v. Pulse Elecs., Inc., No. 14-1513 (U.S. cert granted Oct. 5, 2015), 2015 WL 9450143, at*14 [hereinafter Halo Opening Brief]; Brief for the Petitioners, Stryker Corp. v. Zimmer, Inc., No. 14-1520 (U.S. cert. granted Oct. 19, 2015), 2015 WL 8754930, at *27 [hereinafter Stryker Opening Brief].

207. Seymour, 57 U.S. at 488; Halo Opening Brief, supra note 206, at*14.

208. Stryker Opening Brief, supra note 206, at*32-33.

209. Seymour, 57 U.S. at 489; Brief in Opposition to Petition for a Writ of Certiorari, Halo Elecs., Inc. v. Pulse Elecs., Inc., No. 14-1513 (U.S. cert granted Oct. 5, 2015), 2015 WL 5042893, at *19 [hereinafter Pulse Opposition]; Brief in Opposition, Stryker Corp. v. Zimmer, Inc., No. 141520 (U.S. cert. granted Oct. 19, 2015), 2015 WL 4538188, at *16 [hereinafter Zimmer Opposition].

210. Zimmer Opposition, supra 209, at *17-18. 
malicious" standard that Seymour purportedly endorsed. ${ }^{211}$

With these divergent interpretations, both Petitioners and Respondents agree that the Patent Act of 1952 - the enhanced damages statutory language in the 1952 Act persists today - strove to maintain the status quo at the time of the Act's passage with respect to enhanced damages, which was founded in mid-nineteenth century statutory language and Supreme Court precedent. ${ }^{212}$ Thus, the correct historical interpretation of enhanced damages might influence how the Court interprets $\S 284$ today. And today, the relevant language in the 1952 Act is brief: "[T]he court may increase the damages up to three times the amount found or assessed." ${ }^{213}$ Given this nondescript phraseology, which side's rendition of history will the Supreme Court endorse?

\section{Flexibility Now as Then?}

Perhaps most instructive, according to Petitioners, are cases in which the Court has interpreted other pecuniary sections of the Patent Act. First, two recent cases addressing attorney's fees suggest the Supreme Court might implement a flexible rule where it finds nonrestrictive statutory text. ${ }^{214}$ Specifically, the Court has observed that the section addressing attorney's fees, 35 U.S.C. $\S 285$, just like the text of $\S 284$, imposes "no precise rule or formula" and is, instead, "inherently flexible." ${ }^{215}$ In fact, $\S 284$ is freed from restriction to an even greater extent given that the text of $\S 285$ limits its applicability to "exceptional cases"; without such a restriction in $\S 284$, its text is "even broader" and, as such, "[n]o basis exists for a rigid, multi-prong test that makes any one fact dispositive." 216

Second, the Supreme Court has chided courts for their addition of a common law test to another part of $\S 284$. In General Motors Corp. v. Devex Corp., the Court criticized how an "exceptional circumstances" test had developed "as a matter of federal common law" to control when a court could award prejudgment interest under $\S 284 .{ }^{217}$ The explicit text of $\S 284$ was most telling: "By contrast, $\S 284$ gives a court general authority to fix interest and costs. On the face of $\S$

211. Seymour, 57 U.S. at 489; Pulse Opposition, supra note 209, at *19; Zimmer Opposition, supra note 209 , at $* 16-17$.

212. Zimmer Opposition, supra note 209, at*16-17; Halo Opening Brief, supra note 206, at *14-15; Stryker Opening Brief, supra note 206, at*28.

213. Patent Act of 1952, 66 Stat. 797.

214. See Octane Fitness, LLC v. Icon Health \& Fitness, Inc., 134 S. Ct. 1749 (2014); Highmark Inc. v. Allcare Health Mgmt. Sys., Inc., 134 S. Ct. 1744 (2014). At least one commentator has predicted that "the Supreme Court is very likely to require flexibility — what is unclear is what level of flexibility will be allowed." Dennis Crouch, Supreme Court To Hear Cases on Federal Circuit's Rigid Limits on Treble Damages, Patently-O (Oct. 19, 2015), http://patentlyo.com/patent/2015/10/supreme-circuits-damages.html [https://perma.cc/SA3X-4P38].

215. Octane Fitness, 134 S. Ct. at 1756; Stryker Opening Brief, supra note 206, at*19.

216. Halo Opening Brief, supra note 206 , at $* 18$.

217. General Motors Corp. v. Devex Corp., 461 U.S. 648, 653 (1983); Halo Opening Brief, supra note 206, at*19; Stryker Opening Brief, supra note 206, at*19. 
284, a court's authority to award interest is not restricted to exceptional circumstances, and there is no warrant for imposing such a limitation." 218 According to Petitioners, because both parts of $\S 284$ feature "no limiting language whatsoever," the Court should follow its previous approach from General Motors. ${ }^{219}$

Respondents differs in how they connect the precedential dots. That is, the Supreme Court's treatment of $\S 285$ is unhelpful because $\S 285$ provides for compensatory damages, while $\S 284$ provides for punitive damages. ${ }^{220}$ The punitive damages in $\S 284$ require proof of willful infringement, according to more than a century of precedent, starting with Seymour. ${ }^{221}$ In fact, the Supreme Court and circuit court cases should, according to Respondents, indicate the clear association between punitive damages and willfulness. And given this association, the objective test for willfulness that the Supreme Court formulated in Safeco Insurance Co. of America $v$. Burr is the proper test for punitive damages in $\S 284 .^{222}$ Therefore, because the Seagate test relied on Safeco-which the Supreme Court has yet to overrule - that test should remain the standard for enhanced damages in $\S 284$ and the Federal Circuit's analyses below were correct. $^{223}$

\section{A Boon or a Bust for Defendants?}

Looking ahead, the Supreme Court's decision in these consolidated cases will either strengthen or weaken accused infringers' ability to fend off infringement allegations. If the Court upholds the Seagate test, then developing a reasonable defense could save many accused infringers from facing enhanced damages. If the Court strikes down the Seagate test, then accused infringers might face lessthan-certain obstacles in their efforts to avoid enhanced damages, especially if the Court devises a "totality of the circumstances" approach.

VII. Design Patent Damages: Samsung Electronics Co. V. APple InC.

Not often does a patent case-here, perhaps a patent war-captivate both the international business community and casual news watchers. But then again, never before has a patent case involved devices that appear in the pockets of over a billion people. In 2014, Vanity Fair measured the legal battle between Apple and Samsung as one "on a scale almost unprecedented in business history." 224 And to add to the drama (pun intended), Michael Fassbender received an

218. General Motors, 461 U.S. at 653.

219. Stryker Petition, supra note 204 , at $* 23$.

220. Pulse Opposition, supra note 209, at*14; Zimmer Opposition, supra note 209, at*19.

221. Pulse Opposition, supra note 209, at*14; Zimmer Opposition, supra note 209, at*20.

222. Zimmer Opposition, supra note 209 , at $* 20$.

223. Id.; Pulse Opposition, supra note 209, at *14.

224. Kurt Eichenwald, The Great Smartphone War, VANITY FAIR (May 31, 2014, 8:00 PM), http://www.vanityfair.com/news/business/2014/06/apple-samsung-smartphone-patent-war [https://perma.cc/79KE-LK8M]. 
Academy Award nomination for Actor in a Leading Role for his 2015 portrayal of a named inventor of two of the three design patents at issue. ${ }^{225}$

So here we are! On December 14, 2015, 226 Samsung Electronics Co. among other Samsung entities ("Samsung") filed a petition for a Writ of Certiorari with the U.S. Supreme Court asking the Court to address, in the context of design patents, claim construction and damages. The specific issues are as follows:

1. Where a design patent includes unprotected non-ornamental features, should a district court be required to limit that patent to its protected ornamental scope?

2. Where a design patent is applied to only a component of a product, should an award of infringer's profits be limited to those profits attributable to the component?

\section{A. Procedural History}

At the Federal Circuit, Samsung contested the district court's instructions to the jury, which failed "to exclude the functional aspects of the design patents either in the claim construction or elsewhere in the infringement jury instructions. ${ }^{227}$ But the Federal Circuit found no error. ${ }^{228}$ To the contrary, the court indicated that a proper construction need only "include[] the ornamental aspects of" the patented components and that "it is the non-functional, design aspects that are pertinent to determinations of infringement." 229 As the district court provided jury instructions consonant with these maxims, the Federal Circuit upheld the jury's decision. ${ }^{230}$

Samsung also challenged the district court's damages assessment, which "award[ed] Samsung's entire profits on its infringing smartphones as damages. ${ }^{231}$ According to Samsung, Apple failed to show the patented features caused Samsung's sales-Samsung argued that design patent damages should require such causation. ${ }^{232}$ But according to the Federal Circuit, Congress rejected this "causation" approach to damages and 35 U.S.C. $\S 289$, which provides for design patent damages, "explicitly authorizes the award of total profit from the article of manufacture bearing the patented design." 233

225. 2015 Oscar Nominees, OsCARs, http://oscar.go.com/nominees [https://perma.cc/GL3HQGHC] (last visited May 20, 2016). Here is a hint about which inventor: his name is Steve Jobs.

226. Yes, September 30, 2015, would otherwise be the terminal date for the subject matter of this Article, but as indicated above, the authors could not, in good conscience, fail to preview the case covered in this Section.

227. Apple, Inc. v. Samsung Elecs. Co., 786 F.3d 983, 998 (Fed. Cir. 2015), cert. granted in part, 136 S. Ct. 1453 (2016).

228. Id. at 999.

229. Id.

230. Id.

231. Id. at 1001.

232. Id

233. Id. at 1001-02. The Federal Circuit noted in a footnote twenty-seven law professors in 


\section{B. Supposed Claim Construction Confusion}

Samsung's petition requested clarity amidst the cloudiness of design patent claim construction. To Samsung, it is not what the Federal Circuit has said, it is instead what that court has yet to say. ${ }^{234}$ In particular, although the Federal Circuit has instructed courts to account for ornamental aspects, the Federal Circuit has skirted instructing lower courts about how to address functional features in design patents. $^{235}$

Indeed, Samsung began by noting how design patents protect "any new, original and ornamental design for an article of manufacture.,"236 This language, along with Supreme Court precedent relating design patents to the "decorative arts," should mean that the earlier jury instructions, which never parsed which features should have been within or without the design patents' scopes, were improper. ${ }^{237}$ By requiring express bounds of design patent scope, the Court could cordon off specific intellectual property rights that fall within design patents' purview, just as the Court had done with copyright and trademark law. ${ }^{238}$ Samsung believes the proper, express bounds of that scope include ornamental aspects and exclude functional aspects. ${ }^{239}$

The second part of Samsung's claim construction arguments challenged the Federal Circuit's instructions from Egyptian Goddess, Inc. v. Swisa, Inc. ${ }^{240}$ There, the court reaffirmed that trial courts are not required to provide a verbal description when construing design patents. ${ }^{241}$ But according to Samsung, such leeway permits district courts to avoid providing any "meaningful claim construction," which conflicts with the duty of courts to construe patent claims. ${ }^{242}$ A meaningful claim construction would identify "a design patent's conceptual, functional and ornamental aspects, and instruct a jury not to find infringement based on conceptual or functional similarities." ${ }^{43}$ In short, Samsung asked the Court to determine that design patent construction should exclude functional aspects, just as it includes the ornamental ones (the first part of its claim construction argument), and do so with a clear verbal construction (the second

an amicus brief argued the damages statute, as is, "makes no sense in the modern world." Id. at 1002 n.1. The court then suggested making such arguments to Congress. Id.

234. See generally Petition for a Writ of Certiorari, Samsung Elecs. Co. v. Apple, Inc., No. 15-1777 (U.S. cert. granted in part Mar. 21, 2016), 2015 WL 10435543 [hereinafter Samsung Petition].

235. Id. at $* 21-25$.

236. Id. at $* 4$ (emphasis in original).

237. $I d$. at $* 22$.

238. Id. at $* 23-24$.

239. Id.

240. 543 F.3d 665 (Fed. Cir. 2008).

241. Id. at 679 .

242. Samsung Petition, supra note 234 , at $* 24-25$.

243. Id. at *25. 
part of its argument).

\section{Damages for Modern Designs}

Samsung also sought review of 35 U.S.C. $\S 289$, which provides an infringer is liable for "any article of manufacture ... to the extent of his total profit ... but [the patentee] shall not twice recover the profit made from the infringement." 244 According to Samsung, the Federal Circuit misunderstood two parts of this language. ${ }^{245}$

First, Samsung contended that the Federal Circuit took "article of manufacture" too literally. ${ }^{246}$ Older circuit court cases recognized how such an "article" was meant to be confined to the particular "subject of the patent"; why should patents to constituent parts lead to damages awards based on the sales of whole devices? ${ }^{247}$ What is more, Samsung pointed out how, in the modern context, the Federal Circuit's approach fails to provide a reasonable approach to products such as smartphones, which incorporate thousands of features, each of which could be subject to design or utility patent protection. ${ }^{248}$

Second, Samsung accused the Federal Circuit of ignoring the "made from the infringement" language of the statute. ${ }^{249}$ This language, according to Samsung, creates a causation requirement for the accurate calculation of damages. ${ }^{250}$ Under the Federal Circuit's interpretation, Samsung drew up a doomsday scenario: "[U]nder the Federal Circuit's approach, the ... patentee can obtain $100 \%$ of infringer's profits despite the patent's same minimal contribution." ${ }^{251}$ This could lead to a patentee collecting all of an infringer's profits based on a trivial, although patented, feature in a smartphone. ${ }^{252}$

\section{Big Changes Ahead (Maybe?)}

And so we await the Supreme Court's decision on whether to grant review. Such review might lead to a total reformation in the area of design patent law. In the event of the Supreme Court's denial, however, at least if you ask Samsung, uncertainties would persist in design patent litigation. Will the Supreme Court heed Samsung's pleas? ${ }^{253}$

244. 35 U.S.C. $§ 289$ (2012).

245. Samsung Petition, supra note 234 , at $* 28-32$.

246. Id. at $* 27-32$.

247. Id. at $* 28-29$.

248. Id. at 29 .

249. Id. at 27.

250. Id. at 30 .

251. Id. (emphasis in original).

252. Id. at 31 .

253. On March 21, 2016, the Supreme Court granted certiorari on the second question Samsung presented, which relates to design patent damages. Samsung Elecs. Co. v. Apple Inc., 136 S. Ct. 1453 (2016). 


\section{TACKING AS AN IsSUE of FACT: HANA FINANCIAL, INC. V. HANA BANK}

In Hana Financial, Inc. v. Hana Bank, the U.S. Supreme Court addressed whether tacking in trademark law is an issue of law (i.e., for the judge to decide) or an issue of fact (i.e., for the jury to decide). ${ }^{254}$ In a unanimous decision led by Justice Sonia Sotomayor, the Court held that tacking in trademark law is an issue of fact, primarily because the "inquiry operates from the perspective of an ordinary purchaser or consumer.",255

\section{A. Background}

In 1994, Respondent Hana Bank, formerly Korea Investment Finance Corporation, began offering financial services to Korean expatriates in the United States under the name "Hana Overseas Korean Club." 256 In 1995, Petitioner Hana Financial began using its name in commerce and obtained a federal trademark registration one year later. ${ }^{257}$

In 2007, Hana Financial sued Hana Bank, alleging trademark infringement. ${ }^{258}$ Hana Bank denied infringement "by invoking the tacking doctrine and claiming" it had used its mark in commerce prior to Hana Financial. ${ }^{259}$ After submitting the tacking issue to the jury, the jury returned a verdict of non-infringement in favor of Hana Bank. ${ }^{260}$ Hana Financial appealed to the Ninth Circuit, which affirmed the jury's verdict and the district court's treatment of the tacking doctrine as an issue of fact. ${ }^{261}$ The Court granted certiorari to resolve a split amongst the circuits - whether tacking should be decided by juries (i.e., an issue of fact) or judges (i.e., an issue of law). ${ }^{262}$

\section{B. Analysis}

In affirming the Ninth Circuit, the Court largely reasoned that the tacking doctrine is a question of fact because it requires inquiring into the mind of a consumer, a fact-intensive determination. ${ }^{263}$ As background, tacking, if successfully used, allows a user to maintain an earlier date of the mark's first use in commerce, giving the user priority rights over other users. ${ }^{264}$ Under the doctrine, "two marks may be tacked when the original and revised marks are

254. Hana Fin., Inc. v. Hana Bank, 135 S. Ct. 907 (2015).

255. Id. at 909 .

256. Id.

257. Id. at 910 .

258. Id.

259. Id.

260. $I d$.

261. Id.

262. Id.

263. Id. at 911.

264. Id. at 909 (quoting Van-Dyne-Crotty, Inc. v. Wear-Guard Corp., 926 F.2dd 1156, 1159 (Fed. Cir. 1991)). 
'legal equivalents"” (i.e., the marks " create the same, continuing commercial impression' so that consumers 'consider both as the same mark" "). ${ }^{265}$ As such, and as has long been recognized, "the jury is generally the decisionmaker that ought to provide the fact-intensive answer." 266 Thus, as held by the Court, "when a jury trial has been requested and when the facts do not warrant entry of summary judgment or judgment as a matter of law, the question whether tacking is warranted must be decided by a jury." 267

The Court found that Hana Financial's four arguments to the contrary were unavailing. First, Hana Financial argued "the 'legal equivalents' test involves the application of a legal standard," and thus is a question of law. ${ }^{268}$ The Court responded that the application of a legal standard to facts (i.e., a mixed question of law and fact) has typically been resolved by juries and any concern that exists that a jury may misapply the relevant legal standard can be resolved through proper jury instructions. ${ }^{269}$ Second, Hana Financial argued that because "tacking determinations will create new law that will guide future tacking disputes," judges should decide them. ${ }^{270}$ The Court responded that there is nothing inherently wrong with juries creating precedent and, either way, not all tacking cases need precedent to be resolved. ${ }^{271}$ Third, Hana Financial argued that assigning the tacking determination to juries will create unpredictability in the trademark system. ${ }^{272}$ The Court responded that juries are employed in analogous contexts in other areas of law without issue and such "fact-intensive disputes necessarily requires judgment calls," regardless of whether decided by judge or jury. ${ }^{273}$ Fourth, Hana Financial argued that judges have historically resolved tacking disputes. ${ }^{274}$ The Court responded, however, that all of Hana Financial's case support was inapposite because such cases were tried without a jury, resolved on summary judgment, or the like. ${ }^{275}$

265. Id. at 911.

266. $I d$.

267. $I d$.

268. Id.

269. Id. at 911-12.

270. Id. at 912 (internal quotations omitted).

271. $I d$.

272. Id. at 912-13.

273. $I d$.

274. Id.

275. Id. at 913 . 